\title{
Biological transfer of silver under silver nanoparticle exposure and nitrogen transfer via a collembolan- predatory mite food-chain and ecotoxicity of silver sulfide
}

\author{
Simin $\mathrm{Li}^{1,2}$, Zhu $\mathrm{Li}^{1}$, Xin $\mathrm{Ke}^{3}$, Longhua $\mathrm{Wu}^{1,{ }^{*}}$, Peter Christie ${ }^{1}$ \\ 1 CAS Key Laboratory of Soil Environment and Pollution Remediation, Institute of Soil Science, Chinese Academy of Sciences, \\ Nanjing 210008, China \\ 2 University of Chinese Academy of Sciences, Beijing 100049, China \\ 3 Institute of Plant Physiology and Ecology, Shanghai Institutes for Biological Sciences, Chinese Academy of Sciences, \\ Shanghai 200032, China
}

H I G H L I G H T S

- AgNPs transferred and accumulated though soil animal food chain.

- AgNPs trophic transfer disturbed nutrient element $\mathrm{N}$ transfer.

- Ag accumulated in body tissue, but no biomagnification effects.

- $\mathrm{Ag}_{2} \mathrm{~S}$ was harmful to $F$. candida on survival and reproduction.

\section{ARTICLE INFO}

Article history:

Received July 5, 2021

Revised September 17, 2021

Accepted September 29, 2021

\section{Keywords:}

AgNPs

$\mathrm{Ag}_{2} \mathrm{~S}$

${ }^{15} \mathrm{~N}$

Soil animals

Food chain

\section{GRAPHICAL ABSTRACT}

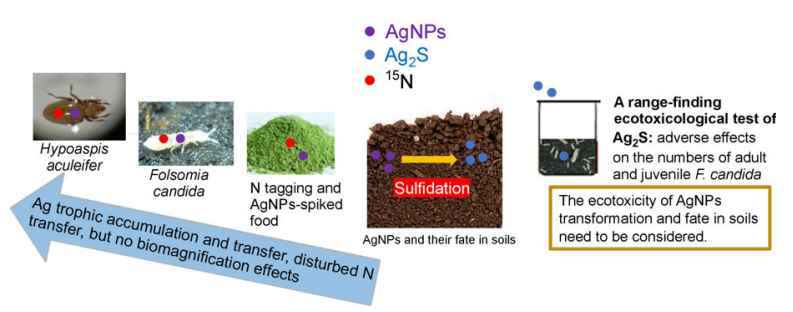

\section{A B S T R A C T}

The development of nanotechnology has accelerated the use of silver nanoparticles (AgNPs) in household chemicals and the accumulation of $\mathrm{Ag}$ in sewage treatment systems. The application of sewage sludge products to soils raises concerns over the safety of $\mathrm{Ag}$ in the function and biogeochemical cycles of the soil belowground ecosystem. Here, we assess the potential risk of the accumulation and transfer of Ag under AgNPs exposure and its effects on the trophic transfer of nitrogen $(\mathrm{N})$ through a soil animal food chain (Folsomia candida-Hypoaspis aculeifer). The formation of stable silver sulfide $\left(\mathrm{Ag}_{2} \mathrm{~S}\right)$ was also studied via a single species test using $F$. candida. Concentrations of $\mathrm{Ag}$ in F. candida increased with increasing AgNPs concentration, as did those in the predator $H$. aculeifer, but the Ag bioaccumulation factors of both animals were $<1$. Folsomia candida body tissue ${ }^{15} \mathrm{~N}$ abundance declined markedly compared with that of $H$. aculeifer. Silver sulfide did have adverse effects on the survival and reproduction of $F$. candida. The $\mathrm{Ag}$ concentrations of $F$. candida increased with increasing $\mathrm{Ag}_{2} \mathrm{~S}$ concentration in sludge-treated soils. Silver sulfide showed ecotoxicity to the collembolan, therefore ecotoxicity resulting from the transformation and fate of AgNPs in soils needs to be considered before biosolid products are applied to agricultural soils.

(c) Higher Education Press 2021

\footnotetext{
* Corresponding author

E-mail address: Ihwu@issas.ac.cn (L. Wu)
}

\section{Introduction}

The development of nanotechnology has accelerated the use of nano-silver (AgNPs) products. Silver nanoparticles have anti-bacterial, plasmonic and opto-electrical properties and are widely used in household chemicals (Kampe et al., 2018), 
resulting in large amounts entering sewage treatment systems adsorbed to sludge. Wu et al. (2018) collected 56 Chinese sludge samples and found $\mathrm{Ag}$ concentrations of $0.64-9.92 \mathrm{mg} \mathrm{kg}^{-1}$. Thus, the application of sewage sludges to agricultural land may lead to AgNPs accumulation in soils (Mueller and Nowack, 2008), raising safety concerns regarding AgNPs in soil ecosystems (Blaser et al., 2008; Wang et al., 2018). Negative effects of AgNPs on microbial biomass and diversity, plant growth and yield, and soil invertebrate survival and reproduction have been documented (Waalewijn-Kool et al., 2014; Wang et al., 2017; Courtois et al., 2019). Soil animals including collembolans, earthworms and enchytraeids have been studied in detail in single species tests at the molecular, individual and population levels of organization (Schlich et al., 2013; Bicho et al., 2016; Sillapawattana et al., 2016). However, multiple species ecotoxicological tests of AgNPs risks in food chains remain limited. Micro-mesocosm studies of biocenoses have greater ecological relevance than single-species tests (Kula and Römbke, 1998). A novel study has advanced our understanding of AgNPs uptake by plants and trophic transfer to herbivores, with transfer of stableisotope-enriched ${ }^{109} \mathrm{AgNPs}$ via soybean leaves and accumulation in snails, indicating risks from AgNPs to the food chain (Dang et al., 2019). A field survey at the site of a nuclear accident at Fukushima, Japan, found that arthropods concentrated more radioactive ${ }^{110} \mathrm{Ag}$ than other soil animals, and this highlights the necessity of studying the influence of AgNPs in belowground terrestrial food chains (Nakanishi et al., 2015). Predator-prey relationships are prevalent in soils and are essential to soil biogeochemical cycling and energy flow. Trophic relationships have been used as a tool to reflect the accumulation and biological transfer of elements among soil animals. For instance, predatory mites can eat collembolans as food items and their typical trophic relationships are essential for soil ecosystem functioning (e.g., organic matter decomposition and nutrient element cycles) (Pey et al., 2014). These two animal groups are prevalent in soils and several species have been adopted as standard animals for singlespecies ecotoxicological tests (Fountain and Hopkin, 2005; Huguier et al., 2015). Zhu et al. (2016) established a soil animal food chain comprising Hypoaspis aculeifer and Folsomia candida to study the influence of $\mathrm{Cd}$ at different trophic levels and its effects on nutrient element transfer. This food chain has been used in ecotoxicological studies of pollutants within trophic levels and the pollution effects on the functioning of soil ecosystems (Zhu et al., 2018). This has allowed our studies of AgNPs effects on belowground terrestrial food chains which, to our knowledge, remain unknown (Kwak and An., 2016).

Nano-silver (0-1000 $\mathrm{mg} \mathrm{kg}^{-1}$ ) exposure reduced $\mathrm{N}, \mathrm{K}$ and $\mathrm{S}$ levels in plant tissues by $0.03-0.69,6.18-37.3$, and $5 \%-$ $25.6 \%$, indicating that the AgNPs exerted negative effects on mineral nutrient uptake and assimilation (Abbas et al., 2019). Therefore, AgNPs may have effects on the transfer of nutrients within trophic levels, a topic that requires further study. Biogeochemical cycles of nutrient elements are an essential ecological function of soil food webs, and $\mathrm{N}$ is a nutrient element vital to organisms. Labeled ${ }^{15} \mathrm{~N}$ has been used to determine the trophic positions of animals in food webs, and generally the average difference in ${ }^{15} \mathrm{~N}$ between trophic levels is 3.4 . However, the ${ }^{15} \mathrm{~N}$ value in animals is greatly affected by pollutants and this has often been used to explore the impacts of pollutants on nutrient transfer and fractionation. Pollution stress may result in food avoidance behavior and/or increased excretion and may then influence the transfer of $\mathrm{N}$ from the diet to consumers. For example, the pesticide lindane elevated the ${ }^{15} \mathrm{~N}$ value in daphnia (Ek et al., 2015) and mercury $(\mathrm{Hg})$-contaminated food increased the ${ }^{15} \mathrm{~N}$ value in snowy egrets (Shaw-Allen et al., 2005). The effects of AgNPs on nutrient transfer within terrestrial soil animal food chains have been seldom studied.

In wastewater treatment plants, sewage usually undergoes sulfidation and then AgNPs are transformed to silver sulfide $\left(\mathrm{Ag}_{2} \mathrm{~S}\right.$ ) (Kaegi et al., 2011; Ma et al., 2014), and AgNPs tend to be sulfided and stabilized as $\mathrm{Ag}_{2} \mathrm{~S}$ (normally >94\%) in the flooded soil environment, with other metal species e.g., AgNPs and $\mathrm{AgCl}$ are present in small amount. In agricultural soils AgNPs occur mainly in the form of $\mathrm{Ag}_{2} \mathrm{~S}$ (Li et al., 2017; He et al., 2019). Therefore, the ecotoxicity of AgNPs transformation and fate in soils must also be considered. Although the solubility and bioavailability of $\mathrm{Ag}_{2} \mathrm{~S}$ are reported to be relatively low, soil arthropods such as the collembolan F. candida (a vital part of soil ecosystems and representative of most soil animals) can take up the soluble fraction of $\mathrm{Ag}$ in pore water through their ventral tube and also by oral intake of $\mathrm{Ag}_{2} \mathrm{~S}$-contaminated soil particles into their bodies, further risking potentially toxic effects. A dosage-related ecotoxicological test of $\mathrm{Ag}_{2} \mathrm{~S}$ in soils is therefore necessary.

Here, AgNPs and the stable form $\mathrm{Ag}_{2} \mathrm{~S}$ in soils were considered. The trophic transfer and accumulation of $\mathrm{Ag}$ under AgNPs exposure and the impacts of AgNPs on the transfer of $\mathrm{N}$ were assessed through a soil animal food chain comprising $F$. candida- $H$. aculeifer. The risks posed by $\mathrm{Ag}_{2} \mathrm{~S}$ in sewage sludge-treated soil were also assessed using the standard soil animal F. candida.

\section{Materials and methods}

\subsection{Collembolan and predatory mite}

The test soil animals were obtained from Aarhus University in Denmark and have been cultured in our laboratory for several years. They were reared in Petri dishes (height $10 \mathrm{~mm}$, diameter $90 \mathrm{~mm}$ ) with a layer of moist plaster of Paris mixed with activated charcoal $(9: 1 \mathrm{w} / \mathrm{w})$ at $20 \pm 1^{\circ} \mathrm{C}$ and $75 \%$ relative humidity with a photoperiod of $16: 8 \mathrm{~h}$ (light/dark). Folsomia candida individuals were fed dried baker's yeast (produced by Angel Yeast Co., Ltd., Yichang, Hubei, China; N content, 6.86 $\pm 0.12 \%$; $[\mathrm{Ag}], 0.05 \mu \mathrm{g} \mathrm{kg}^{-1}$ ) and $H$. aculeifer were fed juvenile 
F. candida twice a week. Distilled water was added to maintain the moisture content. 10-12 d synchronized F. candida individuals and 32-35 d synchronized adult $H$. aculeifer were used in the test (OECD, 2008, 2009).

\subsection{Experimental setup}

\subsubsection{Multiple-species toxicity test}

Dried wheat leaf materials, ${ }^{15} \mathrm{~N}$-labeled $(5.54 \pm 0.07$ atom $\%$; $\mathrm{N}$ content: $2.18 \pm 0.05 \%$ ) were used as food for $F$. candida. The steps in brief were as follows. Wheat (cultivar Yangmai 158) was cultured from seed in a container (length $62 \mathrm{~cm}$, width $48 \mathrm{~cm}$, height $18 \mathrm{~cm}$ ) containing $20 \mathrm{~kg}$ uncontaminated soil in a phytotron for 8 weeks. ${ }^{15} \mathrm{NH}_{4}{ }^{15} \mathrm{NO}_{3}(1 \mathrm{~g}, 10.09$ atom \%; $\mathrm{SRICI}$, China) solution was added to the container weekly as fertilizer (Ke and Scheu, 2008). The harvested wheat litter material was washed with distilled water, dried at $60^{\circ} \mathrm{C}$ and ground with a stainless-steel mill ([Ag] $\left.0.02 \mu \mathrm{g} \mathrm{kg}^{-1}\right)$.

Nano-silver (AgNPs) solution was purchased from Xianfeng Nano Co., Ltd., Nanjing, China (100 mg L ${ }^{-1}, 50 \mathrm{~nm}$, [Ag] $>99 \%$ ). A series of AgNPs solutions were mixed with the ${ }^{15} \mathrm{~N}$ enriched wheat to obtain concentrations of $0,100,200$, and $400 \mathrm{mg} \mathrm{kg}^{-1}$ dry weight food, dried at $60^{\circ} \mathrm{C}$, and stored in desiccators. The Ag concentrations were selected based on previous studies by Waalewijn-Kool et al. (2014) and Sillapawattana et al. (2016).

Food exposure was selected to amplify or reduce the effects of soil properties. Five hundred cleaned and gutvomited F. candida individuals (synchronized for $2 \mathrm{~d}$ ) were introduced into a Petri dish. Spiked wheat was supplied three times a week as food for F. candida. Any moldy food present was removed when new food was added, and distilled water was used to maintain humidity. The animals were exposed at $20 \pm 1^{\circ} \mathrm{C}, 75 \%$ relative humidity and a $16: 8 \mathrm{~h}$ photoperiod. Each treatment was set up in triplicate. After 2 weeks, 100 individuals were collected for the determination the internal $\mathrm{Ag}$ concentration and ${ }^{15} \mathrm{~N}$ content. The remaining individuals were starved for 2 days and then transferred into a clean Petri dish and then 10 cleaned, gut-vomited and synchronized (for 32-35 d) $H$. aculeifer were introduced into each Petri dish to form a food chain (F. candida-H. aculeifer). After 2 weeks, $\mathrm{Ag}$ concentrations and ${ }^{15} \mathrm{~N}$ abundance in $H$. aculeifer body tissues were determined.

\subsubsection{Single-species toxicity test}

Uncontaminated soil samples $(0-20 \mathrm{~cm}$ of soil profile) were taken from a forest zone in Jiangsu Province, east China $\left(31^{\circ} 40^{\prime} 56^{\prime \prime} \mathrm{N}, 118^{\circ} 52^{\prime} 27^{\prime \prime} \mathrm{E}\right)$. This soil has been subjected to ecotoxicity tests on soil animals and no apparent adverse effects were observed (Dai et al., 2018; Li et al., 2020a). The soil is a Ferri-Udic Cambosol with the following selected soil physicochemical properties: $\mathrm{pH}\left(\mathrm{H}_{2} \mathrm{O}\right) 5.10$, water holding capacity (WHC) $32 \%$, organic matter content (OM) $12.3 \mathrm{~g} \mathrm{~kg}^{-1}$ and cation exchange capacity (CEC) $15.2 \mathrm{cmol}(+) \mathrm{kg}^{-1}$. After air-drying at room temperature and sieving ( $2 \mathrm{~mm}), 0.5 \%$ dry sewage sludge (basic physicochemical properties shown in Table S1) was added in each treatment according to GB 15618-2018. A series of ground $\mathrm{Ag}_{2} \mathrm{~S}$ additions ( $\mathrm{Ag}$ concentration >99\%; Alfa Aesar Chemical Co. Ltd., Haverhill, $\mathrm{MA} ; 2-\mathrm{mm}$ sieved) were made to the soil to give $\mathrm{Ag}_{2} \mathrm{~S}$ concentrations of $0,100,200,400$, and $600 \mathrm{mg} \mathrm{kg}^{-1}$. The spiked soil samples were allowed to equilibrate for one week at $50 \%$ of $\mathrm{WHC}$.

Ten cleaned and gut-vomited $F$. candida (synchronized for 10-12 d) individuals were introduced into each test vessel (5.5 cm diameter, $250 \mathrm{~mL}$ volume) containing $30 \mathrm{~g}$ spiked soil. The vessel was covered with plastic film punched with small holes. The animals were cultured in the same conditions as described above. The containers were weighed to maintain water balance twice a week. There were four replicates of each treatment. After 28 days, soil animals were extracted with a controlled temperature gradient extractor. Juveniles and adults were counted under a stereomicroscope (Leica S8 APO, Wetzlar, Germany). The body lengths were measured under a microscope (MS60, Mingmei Optoelectronic Technology Co. Ltd., Guangzhou, China). Concentrations of $\mathrm{Ag}$ in adult and juvenile body tissues were determined.

\subsection{Chemical analysis}

The extracted $F$. candida and $H$. aculeifer individuals were starved for 2 days to remove interfering substances from their gut contents. After cleaning (ultrapure water), rinsing and freeze drying $\left(-80^{\circ} \mathrm{C}\right)$, the animals were weighed (precision \pm $1 \mu \mathrm{g}, \mathrm{XS} 3 \mathrm{DU}$, Mettler Toledo, Columbus, $\mathrm{OH}$ ) and stored in a desiccator at $4^{\circ} \mathrm{C}$ before analysis.

\subsection{1 ${ }^{15} \mathrm{~N}$ isotope analysis}

The weighed animals from multiple species tests were analyzed for the ${ }^{15} \mathrm{~N}$ isotope using a Flash EA 2000 Series Elemental Analyzer connected via a Conflo IV to a DeltaV Advantage isotope ratio mass spectrometer (FLASH-EADELTA-V, Thermo Finnigan, Waltham, MA) (Ek et al., 2015). Precision of the ${ }^{15} \mathrm{~N}$ measurement was $<0.10 \%$. The labeled abundance of the ${ }^{15} \mathrm{~N}$ isotope is expressed directly using atom $\%{ }^{15} \mathrm{~N}$.

\subsubsection{Analysis of $\mathrm{Ag}$ in body tissues}

The animals were digested with $300 \mu \mathrm{L}$ of a mixture of $\mathrm{HNO}_{3}$ (65\%; ultrapure) and $\mathrm{HClO}_{4}$ (70\%; ultrapure, Nanjing Chemical Reagent Co., Ltd.) (7:1 v/v). Prior to analysis, $1 \mathrm{~mL}$ $1 \mathrm{~mol} \mathrm{~L}^{-1} \mathrm{HNO}_{3}$ was added to dissolve the residue (Zhang and van Gestel, 2017; Li et al., 2020a). Silver concentrations in digest solutions were determined by ICP-MS (7700x, Agilent Technologies, Santa Clara, CA). Certified reference material GBW08551 (pork liver, Institute of Geophysical and Geochemical Exploration, Langfang, Hebei, China) was included for quality control and the Ag recoveries ranged from $87.6 \%$ to $108 \%$. The bioaccumulation factors (BAF) of $F$. candida and $H$. aculeifer were calculated using the following formula 
(Scheifler et al., 2002): BAF $=\mathrm{Cc} / \mathrm{Cf}$, where $\mathrm{Cc}$ represents the $\mathrm{Ag}$ concentration in consumer tissues and $\mathrm{Cf}$ the $\mathrm{Ag}$ concentration in the food resource. Here, the form and concentration of AgNPs were not assessed during the intake process, thus the results are simply $\mathrm{Ag}$ concentrations.

\subsection{Statistic analysis}

All data are expressed as mean \pm standard error (SE). Probit regression modeling was used to determine the lethal concentration that reduced survival by $50 \%$ (LC50) and effective concentration that reduced reproduction and growth by $50 \%(E C 50)$ at the $5 \%$ protection level. Significant differences in different treatments were determined by Oneway analysis of variance (ANOVA). Mean values were compared using the Tukey test at the $5 \%$ protection level. Statistical analysis was conducted using Microsoft Excel 2016 and the SPSS 21.0 software package (SPSS Inc., Chicago, IL).

\section{Results}

\subsection{Accumulation and transfer of $\mathrm{Ag}$ in the food chain}

No deaths of $F$. candida and $H$. aculeifer were found in this experiment. The concentrations of $\mathrm{Ag}$ in body tissues of $F$. candida and $H$. aculeifer increased significantly with increasing concentration in AgNPs-spiked food $\left(F_{4,14}=\right.$ 122, $P<0.001 ; F_{4,14}=35.2, P<0.001$ respectively, Fig. 1$)$. The food Ag concentrations (wheat spiked with AgNPscontaminated $F$. candida) were significantly and positively correlated with the concentrations in the corresponding animals: $Y=0.0529 x+3.30, R^{2}=0.972$ ( $F$. candida); $Y=$ $0.175 x+0.689, R^{2}=0.983(H$. aculeifer). In $F$. candida (Fig. 1A) the Ag concentrations in body tissues at 100, 200, 400 and $600 \mathrm{mg} \mathrm{AgNPs} \mathrm{kg}^{-1}$ treatments were 15.3, 27.1, 41.8, and 54.9 times higher than in the control treatment, respectively, with corresponding values in $H$. aculeifer (Fig. 1B) of 2.93, 3.755 .55 and 6.19. Folsomia candida had higher internal $\mathrm{Ag}$ concentrations than $\mathrm{H}$. aculeifer in all AgNPs treatments.

No significant difference was found in BAF values from prey $F$. candida to predator $H$. aculeifer, while the BAF values of $\mathrm{Ag}$ from spiked wheat to $F$. candida decreased with increasing AgNPs concentration (Table 1). The BAF value (from wheat to F. candida) at $600 \mathrm{mg} \mathrm{AgNPs} \mathrm{kg}^{-1}$ treatment was $39.8 \%$ lower than that at $100 \mathrm{mg} \mathrm{kg}^{-1}$.

\subsection{Atom $\%{ }^{15} \mathrm{~N}$ in different trophic levels}

The abundance of ${ }^{15} \mathrm{~N}$ (atom $\%{ }^{15} \mathrm{~N}$ ) in F. candida body tissues declined significantly with increasing spiked AgNPs concentration in wheat $\left(F_{4,14}=12.7, P<0.001\right.$, Fig. 2$)$. The relationship between abundance of ${ }^{15} \mathrm{~N}$ and AgNPs concentration in spiked wheat was negative: $Y=-0.0005 x+1.42, R^{2}$
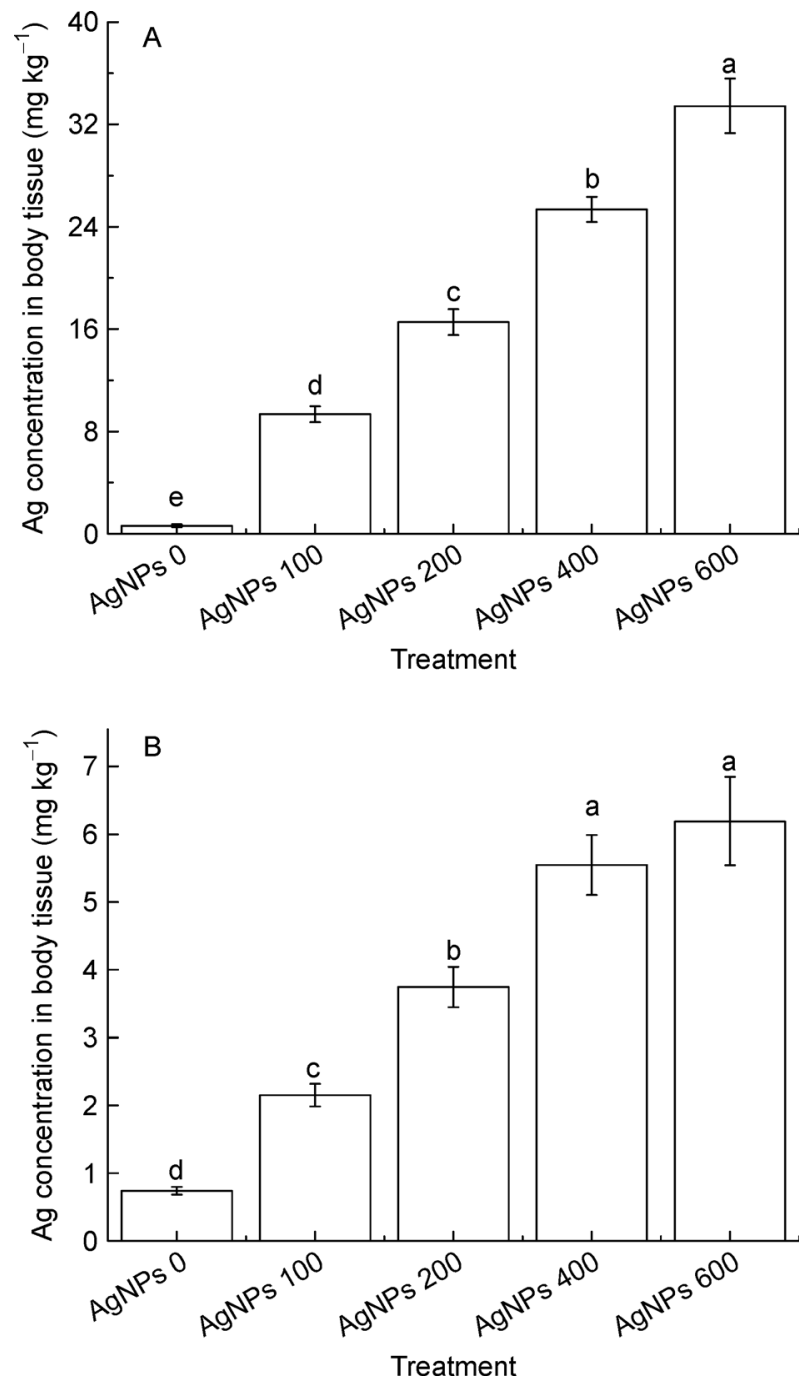

Fig. 1 Silver concentrations in body tissues of $F$. candida (A) and $H$. aculeifer (B) on plate dietary exposure test. Results expressed as mean \pm standard error (SE), $n=3$. Lowercase letters indicate the differences between different treatment means.

$=0.783($ F. candida $), Y=-0.0002 x+0.656, R^{2}=0.806(H$. aculeifer). Atom $\%{ }^{15} \mathrm{~N}$ values in $F$. candida were generally twice as high as in $H$. aculeifer and declined more than in $H$. aculeifer. The atom $\%{ }^{15} \mathrm{~N}$ values of $F$. candida in the control were 1.10,1.19, 1.20 and 1.25 times higher than AgNPs at 100, 200, 400 and $600 \mathrm{mg} \mathrm{kg}^{-1}$, respectively. Significant differences in atom $\%{ }^{15} \mathrm{~N}$ of $\mathrm{H}$. aculeifer bodies were found only at $600 \mathrm{mg} \mathrm{AgNPs} \mathrm{kg}^{-1}, 15.9 \%$ lower than the control.

\subsection{Toxic effects of $\mathrm{Ag}_{2} \mathrm{~S}$ on Folsomia candida}

In the single species test, both survival (the number of adults) and reproduction (the number of juveniles) rates of $F$. candida decreased dramatically with increasing $\mathrm{Ag}_{2} \mathrm{~S}$ concentration in 


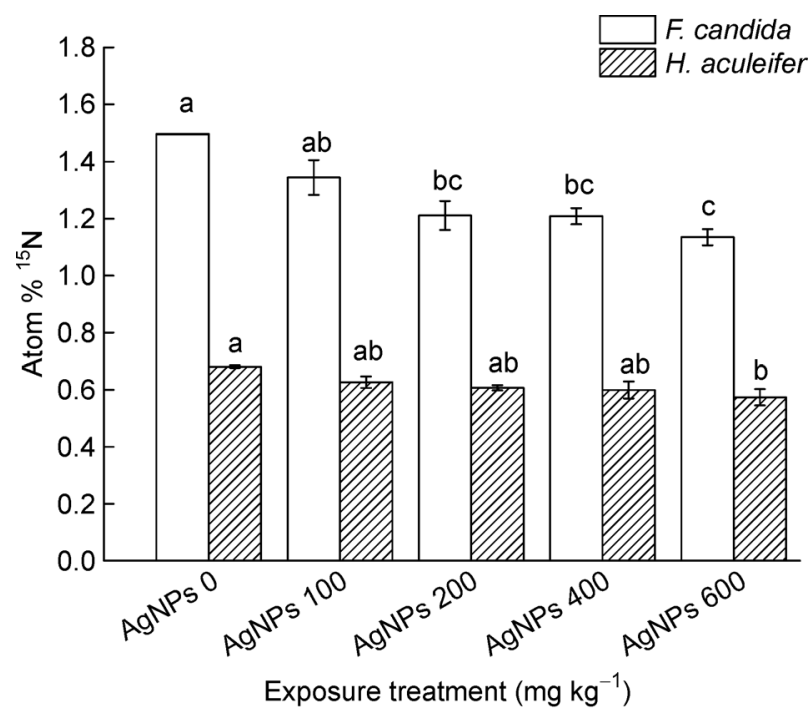

Fig. 2 Atom $\%{ }^{15} \mathrm{~N}$ in body tissues of $F$. candida and $H$. aculeifer on plate dietary exposure test. Results expressed as mean \pm standard error (SE), $n=3$. Lowercase letters indicate the differences between different treatment means.

sludge-treated soils $\left(F_{5,23}=5.34, P<0.005 ; F_{5,23}=17.3\right.$, $P<0.001$, respectively, Fig. 3 ). The adult and juvenile numbers of $F$. candida showed negative relationships with the $\mathrm{Ag}_{2} \mathrm{~S}$ concentration in sludge-treated soils: $Y=-0.0045 \mathrm{x}$ + 9.78 (adult), $R^{2}=0.945, Y=-0.156 x+243, R^{2}=0.921$ (juvenile), respectively. The number of adults started to decrease at $400 \mathrm{mg} \mathrm{Ag}_{2} \mathrm{~S} \mathrm{~kg}{ }^{-1}$ (by $17.9 \%$ ) compared with that at $0 \mathrm{mg} \mathrm{kg}^{-1}$. A decreasing trend in juveniles occurred early at $100 \mathrm{mg} \mathrm{kg}^{-1}$ treatment, decreasing by $16.7 \%$ compared with $0 \mathrm{mg} \mathrm{kg}^{-1}$. The LC50 and EC50 values of $\mathrm{Ag}_{2} \mathrm{~S}$ on F. candida were 831 (697-1078) and 667 (43046738) $\mathrm{mg} \mathrm{kg}^{-1}$. No significant differences in the number of adults and juveniles were found in control and $0 \mathrm{mg} \mathrm{kg}^{-1} \mathrm{Ag}_{2} \mathrm{~S}$ treatments.

The mean body lengths of both adults and juveniles of F. candida in $\mathrm{Ag}_{2} \mathrm{~S}$-spiked sludge-treated treatments showed no significant difference with increasing $\mathrm{Ag}$ concentration $\left(F_{5,23}=0.53, P>0.05 ; F_{5,23}=1.27, P>0.05\right.$ respectively, Fig. 4). The body length of juveniles in the control was significantly lower than that in the $0 \mathrm{Ag}_{2} \mathrm{~S} \mathrm{mg} \mathrm{kg}{ }^{-1}$ treatment, only $83.9 \%$ of the latter $\left(F_{5,23}=6.23, P<0.005\right)$.

Internal Ag concentrations in body tissues of $F$. candida adults and juveniles increased greatly with increasing $\mathrm{Ag}$ concentration in sludge-treated soils $\left(F_{5,23}=11.5, P<0.001\right.$; $F_{5,23}=15.4, P<0.001$ respectively, Fig. 5). The relationship between $\mathrm{Ag}$ concentrations of adult and juvenile $F$. candida bodies and $\mathrm{Ag}_{2} \mathrm{~S}$ concentrations in sludge-treated soils was positive: $Y=0.002 x+0.422, R^{2}=0.868$ (adult), $Y=0.0024 x+$ $0.285, R^{2}=0.903$ (juveniles), respectively. In the 600 $\mathrm{mg} \mathrm{Ag}_{2} \mathrm{~S} \mathrm{~kg}^{-1}$ treatment the internal Ag concentrations in adult and juvenile $F$. candida were 8.35 and 10.3 times higher than in the control.
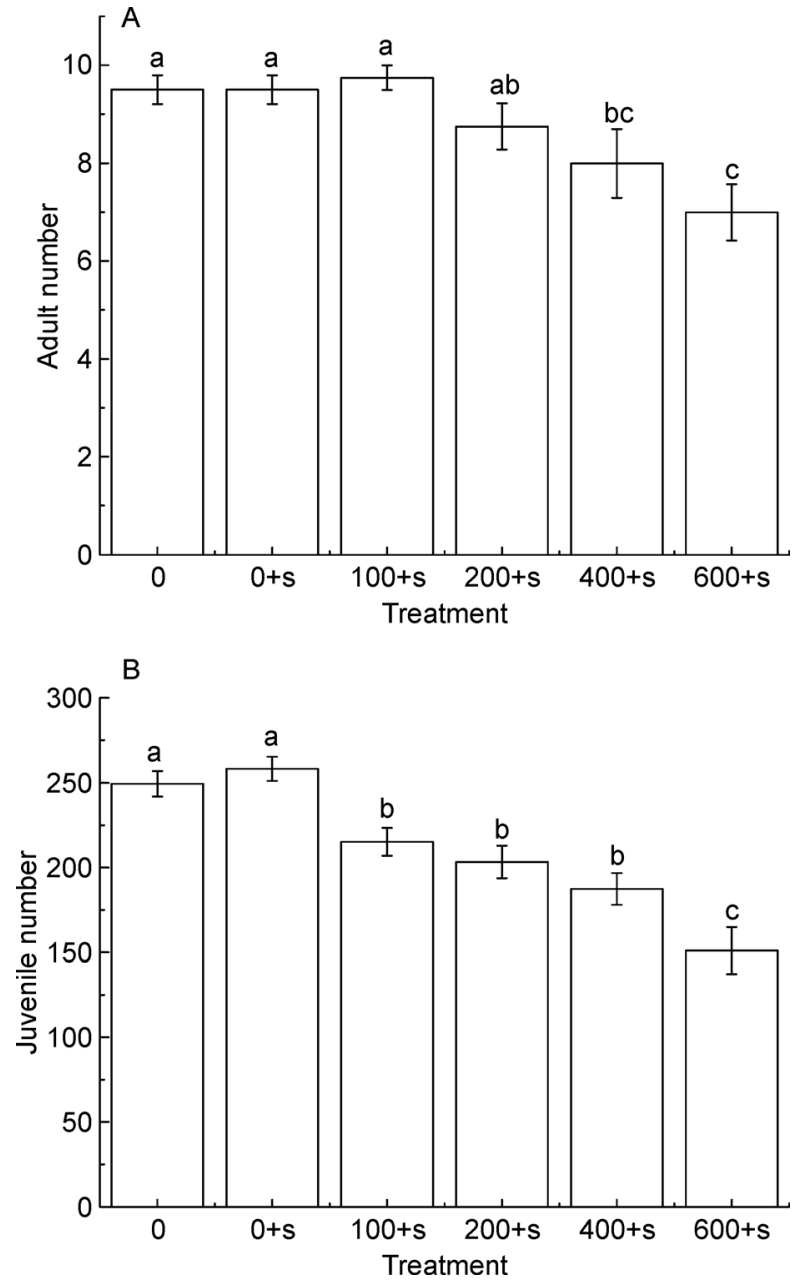

Fig. 3 Number of adults (A) and juveniles (B) in spiked soil after $28 \mathrm{~d}$ of exposure. Results expressed as mean \pm standard error (SE), $n=4$. Lowercase letters indicate the differences between different treatment means.

\section{Discussion}

4.1 Bioaccumulation and trophic transfer of Ag under AgNPs exposure

Multiple species studies are commonly used in higher tier tests for pollutant assessment. These multiple-species integrative tests consider fluctuations within populations and interactions between populations (Hund-Rinke and Kördel, 2003). The internal Ag concentrations in F. candida and $H$. aculeifer increased with increasing AgNPs in the spiked wheat, indicating that $\mathrm{Ag}$ could be transferred through the trophic relationship, with the AgNPs-spiked wheat ingested by F. candida and then transferred to the predator $H$. aculeifer, although it remains unclear which forms of $\mathrm{Ag}$ (Ag nanoparticles and/or dissolved $\mathrm{Ag}$ ions) were ingested by the two arthropods. The dissolution and release of toxic $\mathrm{Ag}^{+}$ions and the physical interaction of nanoparticles make the toxicity of 


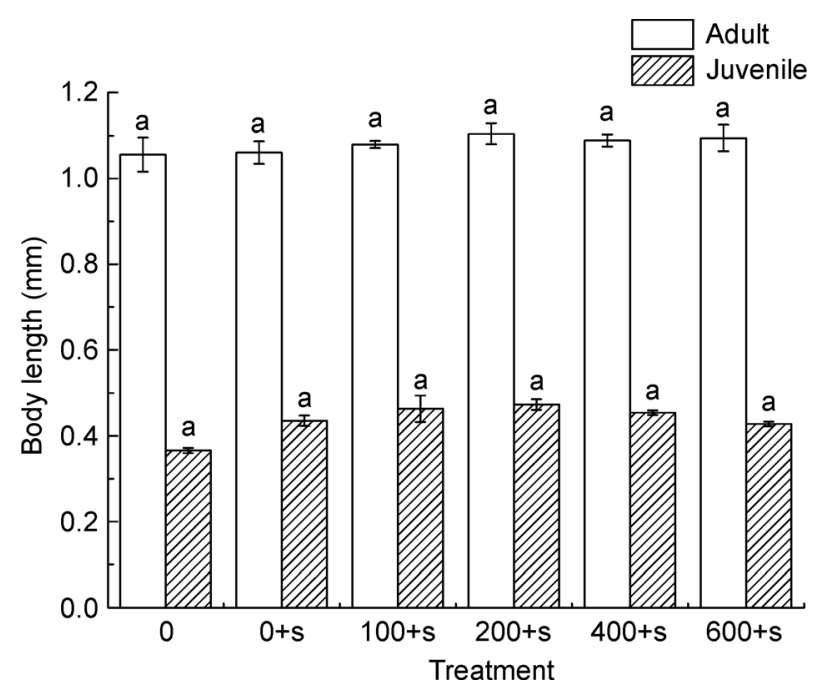

Fig. 4 Body length of adults and juveniles in spiked soil after 28 $\mathrm{d}$ of exposure. Results expressed as mean \pm standard error (SE), $n=4$. Lowercase letters indicate the differences between different treatment means.

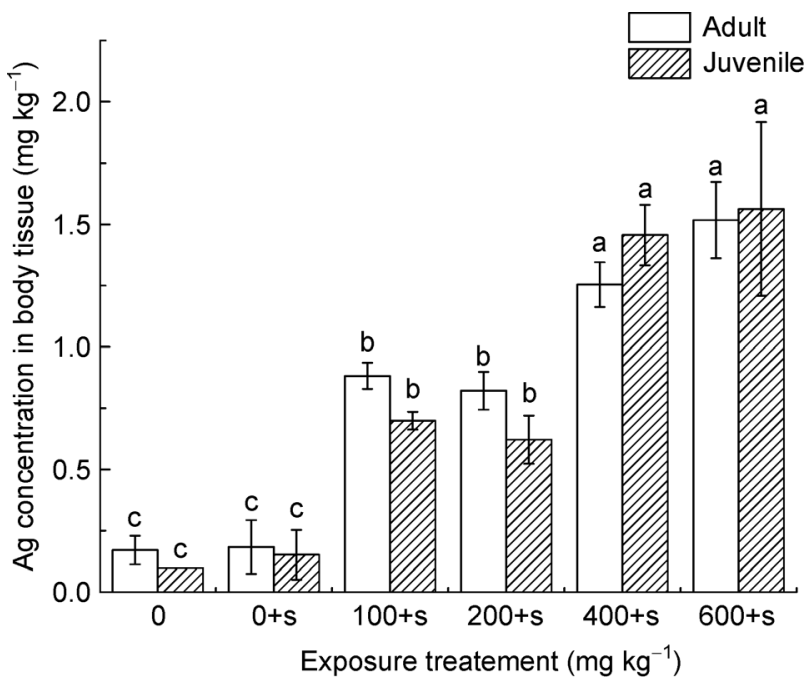

Fig. 5 Silver concentrations in adult and juvenile body tissues in spiked soil after $28 \mathrm{~d}$ of exposure. Results expressed as mean \pm standard error (SE), $n=4$. Lowercase letters indicate the differences between different treatment means.

AgNPs complex. Sillapawattana et al. (2016) found that the released free silver ions and the formation of reactive species were the main causes of AgNPs toxicity in F. candida. A toxicity study of $\mathrm{ZnO}$ nanoparticles on collembolans in soil systems confirmed that $\mathrm{Zn}$ particles, $\mathrm{ZnO}$ nanoparticles, and free $\mathrm{Zn}$ ions all contributed to uptake and toxicity (Tourinho et al., 2013). Comparative studies on the toxicity of AgNPs and $\mathrm{AgNO}_{3}$ indicated that the toxicity of $\mathrm{AgNO}_{3}$ on the survival and reproduction of $F$. candida was higher than that of AgNPs, but higher internal Ag concentrations were found for AgNPs than $\mathrm{AgNO}_{3}$ (Waalewijn-Kool et al., 2014; Mendes et al., 2015).
Schlich et al. (2013) reported similar results with a higher Ag concentration in the earthworm Eisenia andrei under AgNPs exposure than $\mathrm{AgNO}_{3}$ in soil at spiked concentration of 200 $\mathrm{mg} \mathrm{kg}{ }^{-1}$. These results indicate that nanoparticles are available to soil collembolans. Soil animals have different response patterns to $\mathrm{AgNO}_{3}$ and AgNPs. At the cellular level, glutathione reductase, total glutathione and metallothionein showed delayed responses to AgNPs compared to $\mathrm{AgNO}_{3}$, suggesting that AgNPs had a lower $\mathrm{Ag}^{+}$release rate or a lower rate of $\mathrm{Ag}$ uptake. Different patterns of catalase and glutathione S-transferase indicate a specific nanoparticle effect (Mendes et al., 2015). A disorder of antioxidant systems may cause some disorders of their metabolism. Here, the BAF values of $\mathrm{Ag}$ (from spiked wheat to F. candida) decreased with increasing AgNPs in spiked wheat. The collembolans may respond by reducing their intake of Ag-contaminated food or by accelerating $\mathrm{Ag}$ excretion to regulate their metabolism.

Hypoaspis aculeifer is the only soil-living predator among standard organisms (OECD, 2008) but to date studies are limited of its sensitivity and applicability in the assessment of a broader range of chemicals, especially studies on its bioaccumulation of pollutants (Huguier et al., 2015). Bioaccumulation is a sensitive indication parameter that can reflect the risk of pollutants to higher trophic levels (Ardestani et al., 2014). In this experiment, feeding F. candida was the only way for $H$. aculeifer to ingest $\mathrm{Ag}$ and its capture efficiency is highly dependent on the velocity and rate of encounter with $F$. candida (Baatrup et al., 2005). Contaminated F. candida and/or weak $F$. candida (nutrient deficiency by avoidance of contaminated wheat) may restrict its mobility and facilitate predation by $H$. aculeifer. The BAF values (from $F$. candida to $H$. aculeifer) showed no significant difference in this experiment and were all $<1$ (Table 1). The internal metal concentrations were significantly lower in $H$. aculeifer than in $F$. candida, possibly due to dilution during transfer or the pollution effects were not significant. No bioenrichment effects were manifest and too little $\mathrm{Ag}$ was transferred from $\mathrm{F}$. candida to $H$. aculeifer to produce higher toxic effects to higher trophic levels. No deaths of $H$. aculeifer were found here and generally the secondary risk of AgNPs on its survival was not significant.

\subsection{Effects of AgNPs on trophic transfer of nitrogen}

A soil food net is essential for the transfer of substances and energy and $\mathrm{N}$ is an important major nutrient element whose transfer can directly reflect changes in the functioning of food webs. ${ }^{15} \mathrm{~N}$ content is now considered to be a promising bioindicator of the influence of pollution on the biogeochemical cycles of nutrient elements and the provision of soil ecosystem functions due to the important relationship between concentrations of contaminant in consumers and their ${ }^{15} \mathrm{~N}$ values (Ek et al., 2015). Here the relationship between ${ }^{15} \mathrm{~N}$ and AgNPs concentrations in spiked wheat was significantly negative. Considering the feeding habits of $F$. candida and $H$. aculeifer, the only labeled $N$ resources available to them were spiked wheat and $F$. candida, 
Table 1 BAF values for the transfer of Ag to $F$. candida and $H$. aculeifer.

\begin{tabular}{lll}
\hline Exposure treatment & BAF & \\
\cline { 2 - 3 } & F. candida & H. aculeifer \\
\hline AgNPs 100 & $0.093^{\mathrm{a}}$ & $0.23^{\mathrm{a}}$ \\
AgNPs 200 & $0.083^{\mathrm{ab}}$ & $0.23^{\mathrm{a}}$ \\
AgNPs 400 & $0.063^{\mathrm{bc}}$ & $0.22^{\mathrm{a}}$ \\
AgNPs 600 & $0.056^{\mathrm{c}}$ & $0.19^{\mathrm{a}}$ \\
\hline
\end{tabular}

Note: Different letters in the upper right corner indicate the differences between the mean values of different treatments.

respectively. Silver (although it is not clear in which form) was transferred from $F$. candida to $H$. aculeifer and decreased the $\mathrm{N}$ transfer through them at higher concentrations. Collembolans have selective feeding which may avoid polluted food or strengthen their detoxification system to discharge pollutants (Fountain and Hopkin, 2005). A previous study found that the Collembola may alter their excretion rates for detoxification thus affecting stable isotope fractionation (Staaden et al., 2010). Consequently, the inter ${ }^{15} \mathrm{~N}$ of $F$. candida decreased, as did that in $H$. aculeifer.

\subsection{Toxic effects of $\mathrm{Ag}_{2} \mathrm{~S}$ on F. candida}

Soil organisms have different contact models with trace metals in soils. For annelid worms such as earthworms and enchytraeids they may be through oral and dermal routes; arthropods such as collembolans may make contact through ventral tubes and oral routes (Lock and Janssen, 2003; Fountain and Hopkin, 2005). In the case of most trace metals, dissolved or free ions in pore water are the main uptake source and are toxic to collembolans through the ventral tubes. However, results for some undissolved pollutants and several food-exposure tests all indicate that oral uptake is also an important additional route of exposure in collembolans (Lock and Janssen, 2003; Ju et al., 2019; Li et al., 2021). Generally, $\mathrm{Ag}_{2} \mathrm{~S}$ in soils will not readily dissolve in pore water and soil ingestion seems to be the main route of $\mathrm{Ag}_{2} \mathrm{~S}$ exposure to collembolans. Adverse effects may be due to the dissolution of $\mathrm{Ag}_{2} \mathrm{~S}$ particles in the collembolan gut. Here, $\mathrm{Ag}_{2} \mathrm{~S}$ had significant toxic effects on the numbers of adults and juveniles of $F$. candida. The decline in reproduction may be due to energy diversion to self-detoxification processes (Hopkin, 1990). No significant difference was found in the body length, indicating that body length was not sensitive to Ag toxicity. Li et al. (2020b) reported similar results with body length not sensitive in contrast to survival and reproduction in a field soil pollution assessment. Adverse impacts of $\mathrm{Ag}_{2} \mathrm{~S}$ were also observed in soil microbial communities, terrestrial soil isopods and the provision of ecosystem services over longer exposure times or at higher concentrations (Kraas et al., 2017; Kampe et al., 2018; Schlich et al., 2018). Given the Ag concentrations in natural field soils (Kramer et al., 2002), the risk of $\mathrm{Ag}_{2} \mathrm{~S}$ seems quite low. However, our study was a simulated amplification test to demonstrate the ecotoxicity of AgNPs transformation and fate in soils, and the long-term effects of AgNPs and their fate in soils require further study.

\section{Conclusions}

This study has demonstrated the potential risk of accumulation and transfer of Ag under AgNPs exposure and has used quantitative data via tagging $\mathrm{N}$ isotope tracer techniques to reveal the pollution effects of AgNPs on the trophic transfer of $\mathrm{N}$ through a soil animal food chain ( $F$. candida- $H$. aculeifer). Silver under AgNPs exposure was transferred and accumulated from $F$. candida to $H$. aculeifer and disturbed the transfer of the major nutrient $\mathrm{N}$, but no biomagnification effect was found using the Ag BAF values. Silver sulfide had adverse effects on the numbers of adult and juvenile $F$. candida and the inter $\mathrm{Ag}$ concentration in animal bodies increased as $\mathrm{Ag}_{2} \mathrm{~S}$ increased in sludge-treated soils. The ecotoxicity of the transformation and fate of AgNPs in soils should therefore be a matter of public concern.

\section{Acknowledgment}

This research was funded by the National Natural Science Foundation of China (41977136).

\section{Electronic supplementary material}

Supplementary material is available in the online version of this article at https://doi.org/10.1007/s42832-021-0125-z and is accessible for authorized users.

\section{References}

Abbas, Q., Liu, G.J., Yousaf, B., Ali, M.U., Ullah, H., Ahmed, R., 2019. Effects of biochar on uptake, acquisition and translocation of silver nanoparticles in rice (Oryza sativa L.) in relation to growth, photosynthetic traits and nutrients displacement. Environmental Pollution 250, 728-736.

Ardestani, M.M., Oduber, F., van Gestel, C.A.M., 2014. A combined toxicokinetics and toxicodynamics approach to assess the effect of 
porewater composition on cadmium bioavailability to Folsomia Candida. Environmental Toxicology and Chemistry 33, 1570-157.

Baatrup, E., Bayley, M., Axelsen, J.A., 2005. Predation of the mite Hypoaspis aculeifer on the springtail Folsomia fimetaria and the influence of sex, size, starvation, and poisoning. Entomologia Experimentalis et Applicata 118, 61-70.

Bicho, R.C., Ribeiro, T., Rodrigues, N.P., Scott-Fordsmand, J.J., Amorim, M.J.B., 2016. Effects of Ag nanomaterials (NM300K) and Ag salt $\left(\mathrm{AgNO}_{3}\right)$ can be discriminated in a full life cycle long term test with Enchytraeus crypticus. Journal of Hazardous Materials 318, 608-614.

Blaser, S.A., Scheringer, M., MacLeod, M., Hungerbühler, K., 2008. Estimation of cumulative aquatic exposure and risk due to silver: contribution of nano functionalized plastics and textiles. Science of the Total Environment 390, 396-409.

Courtois, P., Rorat, A., Lemiere, S., Guyoneaud, R., Attard, E., Levard, C., Vandenbulcke, F., 2019. Ecotoxicology of silver nanoparticles and their derivatives introduced in soil with or without sewage sludge: A review of effects on microorganisms, plants and animals. Environmental Pollution 253, 578-598.

Dai, W.C., Ke, X., Li, Z., Gao, M., Wu, L.H., Christie, P., Luo, Y.M., 2018. Antioxidant enzyme activities of Folsomia candida and avoidance of soil metal contamination. Environmental Science and Pollution Research International 25, 2889-2898.

Dang, F., Chen, Y.Z., Huang, Y.N., Hintelmann, H., Si, Y.B., Zhou, D. M., 2019. Discerning the sources of silver nanoparticle in a terrestrial food chain by stable isotope tracer technique. Environmental Science \& Technology 53, 3802-3810.

Ek, C., Karlson, A.M., Hansson, S., Garbaras, A., Gorokhova, E., 2015. Stable isotope composition in Daphnia is modulated by growth, temperature, and toxic exposure: implications for trophic magnification factor assessment. Environmental Science \& Technology 49, 6934-6942.

Fountain, M.T., Hopkin, S.P., 2005. Folsomia candida (Collembola): a "standard" soil arthropod. Annual Review of Entomology 50, 201222.

He, D., Garg, S., Wang, Z.M., Li, L.X., Rong, H.Y., Ma, X.M., Li, G.Y., An, T.C., Waite, T.D., 2019. Silver sulfide nanoparticles in aqueous environments: formation, transformation and toxicity. Environmental Science. Nano 6, 1674-1687.

Hopkin, S.P., 1990. Critical concentrations, pathways of detoxification and cellular ecotoxicology of metals in terrestrial arthropods. Functional Ecology 4, 321-327.

Huguier, P., Manier, N., Owojori, O.J., Bauda, P., Pandard, P., Römbke, J., 2015. The use of soil mites in ecotoxicology: A review. Ecotoxicology (London, England) 24, 1-18.

Hund-Rinke, K., Kördel, W., 2003. Underlying issues in bioaccessibility and bioavailability: experimental methods. Ecotoxicology and Environmental Safety 56, 52-62.

Ju, H., Zhu, D., Qiao, M., 2019. Effects of polyethylene microplastics on the gut microbial community, reproduction and avoidance behaviours of the soil springtail, Folsomia candida. Environ Mental Pollution 247, 890-897.

Kaegi, R., Voegelin, A., Sinnet, B., Zuleeg, S., Hagendorfer, H., Burkhardt, M., Siegrist, H., 2011. Behaviour of metallic silver nanoparticles in a pilot wastewater treatment plant. Environmental
Science \& Technology 45, 3902-3908.

Kampe, S., Kaegi, R., Schlich, K., Wasmuth, C., Hollert, H., Schlechtriem, C., 2018. Silver nanoparticles in sewage sludge: Bioavailability of sulfurized silver to the terrestrial isopod Porcellio scaber. Environmental Toxicology and Chemistry 37, 1606-1613.

Ke, X., Scheu, S., 2008. Earthworms, Collembola and residue management change wheat (Triticum aestivum) and herbivore pest performance (Aphidina: Rhophalosiphum padi). Oecologia 157, 603-617.

Kraas, M., Schlich, K., Knopf, B., Wege, F., Kagi, R., Terytze, K., Hund-Rinke, K., 2017. Long-term effects of sulfurized silver nanoparticles in sewage sludge on soil microflora. Environmental Toxicology and Chemistry 36, 3305-3313.

Kramer, J.R., Benoit, G., Bowles, K.C., 2002. Environmental Chemistry of Silver. In: Andren, A., Bober, T., eds. Silver in the Environment: Transport, Fate and Effects. Society of Environmental Toxicology and Chemistry, Pensacola, pp.1-25.

Kula, C., Römbke, J., 1998. Testing organic matter decomposition within risk assessment of plant protection products. Environmental Science and Pollution Research International 5, 55-60.

Kwak, I.J., An, Y.J., 2016. Trophic transfer of silver nanoparticles from earthworms disrupts the locomotion of springtails (Collembola). Journal of Hazardous Materials 315, 110-116.

Li, M., Wang, P., Dang, F., Zhou, D.M., 2017. The transformation and fate of silver nanoparticles in paddy soil: effects of soil organic matter and redox conditions. Environmental Science: Nano 4, 919-928.

Li, S.M., Jia, M.Y., Li, Z., Ke, X., Wu, L.H., Christie, P., 2020 a. Ecotoxicity of arsenic contamination toward the soil enchytraeid Enchytraeus crypticus at different biological levels: Laboratory studies. Ecotoxicology and Environmental Safety 207, 111218.

Li, S.M., Li, J., Li, Z., Ke, X., Wu, L.H., Christie, P., 2021. Toxic effects of norfloxacin in soil on fed and unfed Folsomia candida (Isotomidae: Collembola) and on gut and soil microbiota. Science of the Total Environment 788, 147793.

Li, S.M., Li, Z., Li, J., Ke, X., Wu, L.H., Luo, Y.M., Christie, P., 2020 b. Influence of long-term biosolid applications on communities of soil fauna and their metal accumulation: A field study. Environmental Pollution 260, 114017.

Lock, K., Janssen, C.R., 2003. Comparative toxicity of a zinc salt, zinc powder and zinc oxide to Eisenia fetida, Enchytraeus albidus and Folsomia candida. Chemosphere 53, 851-856.

Ma, R., Levard, C., Judy, J.D., Unrine, J.M., Durenkamp, M., Martin, B., Jefferson, B., Lowry, G.V., 2014. Fate of zinc oxide and silver nanoparticles in a pilot wastewater treatment plant and in processed biosolids. Environmental Science \& Technology 48, 104-112.

Mendes, L.A., Maria, V.L., Scott-Fordsmand, J.J., Amorim, M.J.B., 2015. Ag nanoparticles (Ag NM300K) in the terrestrial environment: Effects at population and cellular level in Folsomia candida (Collembola). International Journal of Environmental Research and Public Health 12, 12530-12542.

Mueller, N.C., Nowack, B., 2008. Exposure modelling of engineered nanoparticles in the environment. Environmental Science \& Technology 42, 4447-4453.

Nakanishi, H., Mori, A., Takeda, K., Tanaka, H., Kobayashi, N., Tanoi, 
K., Yamakawa, T., Mori, S., 2015. Discovery of radioactive silver $(\mathrm{Ag}-110 \mathrm{~m})$ in spiders and other fauna in the terrestrial environment after the meltdown of Fukushima Dai-ichi nuclear power plant. Proceedings of the Japan Academy: Series B, Physical and Biological Sciences 91, 160-174.

OECD, 2008. Guidelines for the Testing of Chemicals No. 226 Predatory Mite (Hypoaspis Aculeifer) Reproduction Test in Soil. Organisation for Economic Cooperation and Development, Paris, France.

OECD, 2009. Guidelines for the Testing of Chemicals No. 232, Collembolan Reproduction Test in Soil. Organisation for Economic Cooperation and Development, Paris, France.

Pey, B., Nahmani, J., Auclerc, A., Capowiez, Y., Cluzeau, D., Cortet, J., Decaens, T., Deharveng, L., Dubs, F., Joimel, S., Briard, C., Grumiaux, F., Laporte, M.A., Pasquet, A., Pelosi, C., Pernin, C., Ponge, J.F., Salmon, S., Santorufo, L., Hedde, M., 2014. Current use of and future needs for soil invertebrate functional traits in community ecology. Basic and Applied Ecology 15, 194-206.

Scheifler, R., Vaufleury, G.D., Toussaint, M.L., Badot, P.M., 2002. Transfer and effects of cadmium in an experimental food chain involving the snail Helix aspersa and the predatory carabid beetle Chrysocarabus splendens. Chemosphere 48, 571-579.

Schlich, K., Hoppe, M., Kraas, M., Schubert, J., Chanana, M., HundRinke, K., 2018. Long-term effects of three different silver sulfide nanomaterials, silver nitrate and bulk silver sulfide on soil microorganisms and plants. Environmental Pollution 242, 1850 1859

Schlich, K., Klawonn, T., Terytze, K., Hund-Rinke, K., 2013. Effects of silver nanoparticles and silver nitrate in the earthworm reproduction test. Environmental Toxicology and Chemistry 32 181-188.

Shaw-Allen, P.L., Romanek, C.S., Bryan, A.L., Brant, H., Jagoe, C.H., 2005. Shifts in relative tissue $\delta^{15} \mathrm{~N}$ values in snowy egret nestlings with Dietary Mercury Exposure: a marker for increased protein degradation. Environmental Science \& Technology 39, 42264233.

Sillapawattana, P., Gruhlke, M.C.H., Schaffer, A., 2016. Effect of silver nanoparticles on the standard soil arthropod Folsomia candida
(Collembola) and the eukaryote model organism Saccharomyces cerevisiae. Environmental Sciences Europe 28, 2-12.

Staaden, S., Milcu, A., Rohlfs, M., Scheu, S., 2010. Fungal toxins affect the fitness and stable isotope fractionation of Collembola. Soil Biology \& Biochemistry 42, 1766-1773.

Tourinho, P.S., van Gestel, C.A.M., Lofts, S., Soares, A.M.V.M., Loureiro, S., 2013. Influence of soil pH on the toxicity of Zinc oxide nanoparticles to the terrestrial isopod Porcellionides pruinosus. Environmental Toxicology and Chemistry 32, 2808-2815.

Waalewijn-Kool, P.L., Klein, K., Fornies, R.M., van Gestel, C.A.M., 2014. Bioaccumulation and toxicity of silver nanoparticles and silver nitrate to the soil arthropod Folsomia candida. Ecotoxicology (London, England) 23, 1629-1637.

Wang, P., Lombi, E., Menzies, N.W., Zhao, F.J., Kopittke, P.M., 2018. Engineered silver nanoparticles in terrestrial environments: a meta-analysis shows that the overall environmental risk is small. Environmental Science. Nano 5, 2463-2774.

Wang, P., Lombi, E., Sun, S.K., Scheckel, K.G., Malysheva, A., McKenna, B.A., Menzies, N.W., Zhao, F.J., Kopittke, P.M., 2017. Characterizing the uptake, accumulation and toxicity of silver sulfide nanoparticles in plants. Environmental Science: Nano 4, 448-460.

Wu, L.H., Yang, L., Wang, Z.Y., Cheng, M.M., Li, Z., Liu, W.X., Ma, T.T., Christie, P., Luo, Y.M., 2018. Uptake of silver by brown rice and wheat in soils repeatedly amended with biosolids. Science of the Total Environment 612, 94-102.

Zhang, L.L., van Gestel, C.A.M., 2017. The toxicity of different lead salts to Enchytraeus crypticus in relation to bioavailability in soil. Environmental Toxicology and Chemistry 36, 2083-2091.

Zhu, D., Bi, Q.F., Xiang, Q., Chen, Q.L., Christie, P., Ke, X., Wu, L.H., Zhu, Y.G., 2018. Trophic predator-prey relationships promote transport of microplastics compared with the single Hypoaspis aculeifer and Folsomia candida. Environmental Pollution 235, 150-154.

Zhu, D., Ke, X., Wu, L.H., Christie, P., Luo, Y.M., 2016. Biological transfer of dietary cadmium in relation to nitrogen transfer and $\mathrm{N}$ 15 fractionation in a soil collembolan-predatory mite food chain. Soil Biology \& Biochemistry 101, 207-216. 